\title{
Yunus Emre'yi Türk Dili ve Edebiyatı Derslerinde Nasıl Anlatırız? Değerler Öğretimi Bağlamında “Yunus Emre: Aşkın Sesi” Filmi Örneği
}

\section{How do we Teach Yunus Emre in Turkish Language and Literature Classes? Example of the Film "Yunus Emre: The Voice of Love" in the Context of Teaching Values}

\author{
Muhammet YILMAZ ${ }^{(1 D}{ }^{1}$, Doç. Dr. Ayşe Derya ESKIMEN (iD) ${ }^{2}$
}

\begin{abstract}
$\ddot{\mathbf{O} z}$
Yunus Emre, hem ulusal hem evrensel değer öğretilerini şiirle buluşturan ve okuruna insanlığın kaybetmemesi gerektiği değerleri hatırlatan, sevgi, inanç, hoşgörü, sayg1 temsilcisi bir hatırlatıcıdır. Bu yönüyle Yunus Emre, Türk insanının kültürel belleğinde asırlardır yer etmiş, eserleri Divan-1 İlahiyat ve Risaletü’n Nushiyye ile Arapça ve Farsçanın kültürel, dilsel kıskacındaki Türkçeye hem nefes vermiş hem de Anadolu'da Türkçenin yazı dili olarak dirilişine öncülük etmiştir. Bu çalışmada, Yunus Emre'nin çağları aşarak günümüze kadar gelen ve kültürel belleğimize yer eden öğretileri, bunların Türk dili ve edebiyatı dersi ve programı kapsamında gençlere film yoluyla aktarımı ele alınmıştır. Türk dili ve edebiyatı dersinin değerler eğitimindeki önemini belirleyen etken edebiyatın doğasından kaynaklanır. Çünkü edebiyatın merkezinde edebî eserler, bu eserlere konu olan insan; insanı anlama ve anlatma gayreti vardır.Çalışmada, değerleri kapsamında ele alacağımız Yunus Emre'nin değer öğretisinin merkezinde insan, insanın merkezinde ise gönül vardır. İnsan gönlü; kırılmaması, kirletilmemesi ve daima cümle kötü duygulardan uzak tutulması gereken yerdir. Yunus Emre, insana dair bütün eğitsel çabanın nihai amacının aslında insanın kendine ve özündeki değerlerine ulaşmak olduğunu vurgular. Buna bağlı olarak çalışmanın amaç ve kapsamını değerler eğitimi bağlamında, Türk dili ve edebiyatı dersinde kullanılabilir bir materyal olarak Yunus Emre: Aşkın Sesi sinema filmi oluşturmaktadır. Araştırmada nitel araştırma yöntemlerinden "doküman incelemesi" kullanılmıştır. Elde edilen bulgulardan hareketle değerlendirme ve önerilerde bulunulmuştur.
\end{abstract}

Anahtar Kelimeler: Yunus Emre, Türk dili ve edebiyatı, değer, film

Makale Türü: Araştırma

\begin{abstract}
Yunus Emre is a representative reminder of love, faith, tolerance, respect, which combines both national and universal value teachings with poetry and reminds its reader of the values that humanity should not lose. In this aspect Yunus Emre Turkish cultural memory of the people has taken place for centuries, works of Divan-1 İlahiyat and Risaletü'n Nushiyye Arabic and Persian cultural, linguistic, clamp both gave both languages in Anatolia Turkish written language led to the resurrection as breathing. In this study, Yunus Emre's teachings, which have transcended the ages and are included in our cultural memory, and their transfer to young people through film within the scope of the Turkish language and literature course and program, were discussed. The factor determining the importance of Turkish language and literature course in values education is due to the nature of literature. Because at the center of literature are literary works, the person who is the subject of these works; the effort to understand and tell the person. In the study, at the center of Yunus Emre's value teaching, which we will consider within the scope of values, there is a person, and at the center of a person is the heart. Human heart; it is a place
\end{abstract}

\footnotetext{
${ }^{1}$ Saray Şehit Murat Dilmaç Anadolu İmam Hatip Lisesi, Saray, Van, muhammedyilmaz71@gmail.com

${ }^{2}$ Kütahya Dumlupınar Üniversitesi, Eğitim Fakültesi, Türkçe ve Sosyal Bilimler Eğitimi Bölümü, deryaeskimen@ @otmail.com
}

Atıf için (to cite): Yılmaz, M., \& Eskimen, A. D. (2021). Yunus Emre'yi Türk dili ve edebiyatı derslerinde nasıl anlatırı? Değerler öğretimi bağlamında "Yunus Emre: Aşkın Sesi” filmi örneği. Afyon Kocatepe Üniversitesi Sosyal Bilimler Dergisi, 23(Yunus Emre ve Türkçe Özel Sayısı), 123-137. 
where it should not be broken, polluted, and always kept away from bad feelings. Yunus Emre emphasizes that the ultimate goal of all human educational efforts is actually to achieve human self and its core values. Accordingly, the purpose and scope of the study in the context of values education is Yunus Emre: The Voice of love cinema film as a material that can be used in the course of Turkish language and literature. "Document review" from qualitative research methods was used in the research. Based on the results obtained, evaluations and recommendations were made.

Keywords: Yunus Emre, Turkish language and literature, value, film

Paper Type: Research

\section{Giriş}

1240/1-1320/1 yılları arasında yaşadığ1 kuvvetle muhtemel olan Yunus Emre'nin menkıbeleşen hayatına dair bilgiler, elde edilen kaynaklara göre tamamen yok edilemeyen bazı şüphelere sahiptir (Köprülü, 1976; Tatc1, 2016). Yunus Emre'nin yaşamına dair ilk bilgiler UzunFirdevsî (ö. 918/1512) tarafından kaleme alınan Vilâyetnâme-i Hacı Bektâş̧-1 Velî̀ye aittir (Tatc1, Yûnus Emre, 2013). Vilâyetnâme-i Hacı Bektâş-1 Velî’ye göre Yunus Emre, fakir bir rençberdir. Kitlı̆̆ın olduğu bir yıl Yunus Emre, buğday almak için yanında biraz alıçla Hacı Bektaş-1 Velî’nin yanına gider ve kendisinden buğday talep eder. Hacı Bektaş-1 Velî, Yunus Emre'nin buğday talebine karşılık ona nefes vermeyi teklif eder. Yunus buğdayda 1srarcı olur ve nihayetinde buğdayı alarak dergâhtan ayrılır. Yunus Emre yolda hatasını anlayarak dergâha geri döner ve "nefes" talep eder. Hacı Bektaş-1 Velî, Yunus Emre'ye "senin anahtarını Tapduk Emre'ye verdik" diyerek onu Tapduk Emre'ye gönderir (Köprülü, 1976). Yunus Emre'nin zahirden batına, tarikattan hakikate olan nefis yolculuğu böyle başlar. Yunus'un Tapduk Emre'nin dergâhında uzun yıllar hizmet ettiği hatta kızı Bacım Sultan ile evlendiği de rivayetler arasındadır (Şahin, 2011; Tatc1, 2013).

Araştırmacılar arasında ümmîliği ve nereli olduğu tartışma konusu olan Yunus Emre'nin günümüzde başta Eskişehir ve Nallıhan olmak üzere birçok yerde makamı vardır. Makamı, Anadolu'nun farklı coğrafyasına; şiiri, Türk insanının vefalı kültürel belleğine asırlardır layık görülen Yunus Emre'nin Divan-1 İlahiyat ve Risaletü'n Nushiyye olmak üzere iki eseri mevcuttur. Eserleri ile Arapça ve Farsçanın kültürel, dilsel kıskacındaki Türkçeye hem nefes vermiş hem de Anadolu'da Türkçenin yazı dili olarak dirilişine öncülük etmiştir.

\section{Değerler Eğitimi, Türk Dili ve Edebiyatı Dersi, Yunus Emre Öğretileri}

Kökeni Eski Türkçedeki "teg-" fiiline varan "değer" kelimesi "pay, hisse, kıymet, muteber" anlamlarına gelmektedir (Nişanyan, 2020). Kelimenin günümüz Türkçesindeki anlam kapsamını şu şekilde belirtmek mümkün: Bir nesnenin talep oranına bağlı olarak fiyat artışındaki maddi değer ve birey ya da toplum tarafından kabul gören, muteber, manevi değer.

Değerler ile ilgili farklı tasnifler yapılmıştır. Nelson'a göre değerler bireysel, grup ve sosyal değerler olmak üzere üçe ayrılır (Yazıc1, 2006). Bireysel değerler kişisel algımızı, grupsal değerler grup yapımızı, sosyal değerler ise toplumsal kişiliğimizi belirler. Dolayısıyla ister birey, ister grup ister toplumsal yapı olsun her durumda "değer" denilen muteber yargılar ya da normlar vardır (Cemiloğlu, 2020). Kısaca değerler; insan için oluşumu birincil çevre olarak aile ile başlayan, yaşanılan toplum ve dünya ile çevrelenen, sözel olmayan ama bazen yaptırımı bile zorlayan manevi kültürel normlardır.

Zaman zaman bireysel ile toplumsal, ulusal ile evrensel çatışmalara karşın her ulus kendi değerlerini diğer nesillere aktarmaya ya da öğretmeye özen göstermiştir. Değerlerin öğretilmesi ya da aktarılmasıyla ilgili temelde dört yaklaşım öne çıkmıştır: Telkin yöntemi, değerlerin açıklanması, değer analizi, ahlaki muhâkeme (Yazıcı, 2006). Telkin yönteminde, var olan toplumsal değerlerin öğrencilere aktarılması söz konusudur. Bireyden çok toplum önceliklidir. Değerlerin açıklanmasında, değerler açıklanarak öğrencilerin değerler hakkında bir kanıya varması amaçlanır (Urlu, 2020). Değer analizinde ise öğrencilerin değerler arasında bağ 
kurması, karşılaştırması, ayrıntılı incelemesi istenen durumdur (Yazıcı, 2006). Ahlakî muhâkeme yöntemi Kohlberg'in ahlakî durumu ve çatışmaları konu alan çalışmalarına dayanır. Öğrencilerin ahlakî ikilemlere, çatışmalara, problemlere sahip örnek olaylardan hareketle ahlakî durumları içselleştirerek kendi değer yargılarına ulaşmalarına yardımcı olmak yöntemin temel hedefidir (Yazıc1, 2006; Urlu, 2020). Kohlberg'e göre evrensel değerlere ulaşmak arzusu bireyin kendini gerçekleştirme amacına hizmet eder (Cemiloğlu, 2020). Değer öğretimi yöntemlerinden de anlaşılacağı üzere değerler bireycilik ile toplumculuk arasında sıkışmaya maruz kalabilir (Altıntaş, 2012). Bazı yaklaşımlar toplumun değerlerini bazı yaklaşımlar bireyin düşüncesini önceler. Bunun nedeni değerlerin toplumdan topluma hatta bireyden bireye dahi değişebilir olmasıdır. Değer değiştiği gibi bir değere atfedilen önem derecesi de değişebilir (Reboul, 1995). $\mathrm{Bu}$ değişkenlik ortamında toplumun ortak değerlerini bireyin kabul etmeme veya reddetme durumu ortaya çıkabilir. Tam bu noktada "değerler eğitimi nasıl olmalıdır?" sorusu ortaya çıkar. Toplumların kendi bireylerine millî değerlerini aktarmak için kullandıkları iki temel unsur vardır: eğitim ve okul. Eğitimin en temel amacı bireyin yaşadığı topluma, zamana, kültüre uygun düşünce ve davranışa sahip olmasını sağlamaktır (Karakaya, 1998; Cemiloğlu, 2020). İnsanın yaşadığı topluma, kültüre uygun davranmasını sağlamak ise bireyin düşüncesini eğitmekten, esnetmekten geçer. Çünkü İnsanların ortak yaşam kültürü oluşturabilmesindeki en önemli faktör düşüncedir. Düşünce bizim hem kendimize hem de bizim dışımızdaki insanlara bakışımızı şekillendirir. Düşünceyi etkileyen, genişleten, ona bilinmeyen kapılar açan ve en önemlisi esneklik sağlayan etken ise eğitimdir. Eğitimin öncelikli hedefi bu nedenle esnek, yaratıcı, çoklu ve çoksesli yaşama dair öğrencilerin zihin, kalp ve düşünce dünyalarını yeniden yapılandırmak ve onu esnetmektir. Okul ise bireyde istenilen bu düşünce, değer dünyasının oluşturulması gereken yer olarak kabul edilmektedir (Yaylacı, 2016).

Millî Eğitim Temel Kanunu'nda (MEB, 1973) eğitimin amacı genel olarak, “Atatürk milliyetçiliğine bağl1, millî-insanî değerleri benimseyen, milletine ve devletine karşı sorumluğunun bilincinde olan, yaratıcı düşünceye sahip" bireyler yetiştirmek olarak belirtilmiştir. Söz edilen kanunundaki "Türk Milletinin bütün fertlerini” (MEB, 1973, s. 5101) ifadesi ise hem hedef kitleyi sınırlandırması hem de hedefin ulusallığını vurgulaması açısından önem arz eder. Ortaögretim Türk Dili ve Edebiyatı Dersi (9,10, 11 ve 12. Sinıflar) Öğretim Programı (MEB, 2018), Millî Eğitim Temel Kanunu'ndan farklı olarak hedeflenen değerler açısından daha özel ve nettir.Değerlerin ulus için önemi şu cümlelerle ifade edilmiştir: "Bir toplumun geleceğinin, değerlerini benimsemiş ve bu değerleri sahip olduğu yetkinliklerle ete kemiğe büründüren insanlarına bağlı olduğu tartışma götürmez bir gerçektir. Bundan dolayı eğitim sistemi, her bir üyesine uygun ahlaki kararlar alma ve bunları davranışlarında sergileme yeterliliğini kazandırma amacıyla hareket eder" (MEB, 2018, s. 5-6). Öğretim programında, araştırma konusunun da bir parçasını oluşturankök değerlere "adalet, dostluk, dürüstlük, öz denetim, sabır, saygı, sevgi, sorumluluk, vatanseverlik, yardımseverlik" şeklinde yer verilmiştir (Eskimen, 2018a; MEB, 2018).

"Okuma, yazma ve sözlü iletişim” üst başlıklarına sahip Ortaöğretim Türk Dili ve Edebiyatı Öğretim Programı'nda (MEB, 2018, s. 20, 22, 24, 25, ), değer öğretimine ilişkin tespit edilen kazanımlar şunlardır:

- Metinde millî, manevi ve evrensel değerler ile sosyal, siyasi, tarihî ve mitolojik ögeleri belirler.

Sözü edilen kazanıma şiir, öyküleyici (anlatmaya bağlı) edebî metinler (masal/fabl, destan, mesnevi, hikâye, roman vb.), tiyatro ve öğretici metinler başlıklarında birer kez toplamda ise dört kez yer verildiği fakat yazma, konuşma ve dinleme başlıklarında değerlere ilişkin bir kazanıma yer verilmediği tespit edilmiştir. Program perspektifinde dahi önce değerlere sonra yetkinliklere yer verilmesi yetkinliklerin değerler üzerine inşa edilirse anlam kazanacağını gösteren bir göstergedir. 
Eskimen (2018a) tarafindan yapılan çalışmada ise 9. ve 10. Sınıf Türk Dili ve Edebiyatı ders kitaplarında çok işlenen değerin sevgi en az işlenen değerin ise sabır olduğu saptanmıştır.

Okullarda değerler eğitimini konu alan ve öğrencilerin değerler eğitimi kazanımını amaçlayan derslerden biri Türk dili ve edebiyatı dersidir. Ortaögretim Türk Dili ve Edebiyatı Dersi (9,10, 11 ve 12. Sinıflar) Öğretim Programı (MEB, 2018, s. 12) özel amaçlarında şu ifadelerle değerler eğitimi vurgulanır:

- Türk edebiyatına ait eserler aracılığıyla millî, manevi, ahlaki, kültürel ve evrensel değerleri anlamaları.

Türk dili ve edebiyatı dersinin değerler eğitimindeki önemini belirleyen etken edebiyatın doğasından kaynaklanır .Günümüz yazınsal anlamından farklı bile olsa edebiyat kelimesinin edep kelimesinden türetilmiş olması (Okay, 1994) gelenekte edebiyatın zihni terbiye etmesi, eğitmesi, estetikleştimesine olaninancı ifade eder.

Malzemesi olan dilde yaratımın bütün esnekliğini kullanan edebiyat, etki gücünü de sözün, dilin büyüsüne borçludur (Okay, 1994). Wittgenstein (2018, s. 133), dilin insan için önemini "Dilimin sınırları, dünyamın sınırlarını imler." sözü ile ifade eder. Sözcüklere anlam katarak sözlü, yazılı dilsel ürünler yaratan edebiyat hem bireyin hem de toplumun kimliğini yansıtır. Bu açıdan edebiyatı, toplumun benliğini ve benlik edinme sürecini yansıtan en önemli unsurlarından biri olarak değerlendirmek mümkündür (Alver, 2006). Edebiyat ile toplum arasındaki güçlü ilişki "edebiyat $\mathrm{m}$ toplumun, toplum mu edebiyatın belirleyişidir" sorusuna kadar varmıştır (Karakaya, 1998). Var olduğu toplumu bu derece yakından betimleyen eserlere sahip bir alanın toplumun değer yargılarına da hâkim olması kaçınılmazdır. Bu nedenle Türk dili ve edebiyatı derslerinde edebiyat ürünleri aracılığ 1 ile öğrencilerin değerler eğitimine katk1 sunulması mümkündür.

Edebiyat eserlerindeki ikilem, ahlakî bunalım (Cemiloğlu, 2020), zulüm, merhamet, sorumluluk, yalancılık, vatanseverlik, iyilik gibi değer yargılarını yansıtan sahneler, diyaloglar hem öğrencilerin kurgudaki yansımalarını görmelerine hem de var olan değerlerle ilgili kendi çıkarımlarını yapmalarına olanak sağlar.

Edebiyat eserlerinde değerler bazen doğrudan bazense kurgu içine serpiştirilmiş halde karşımıza çıkar. Zira yazar bazen doğrudan telkin yöntemi ile bazen ise sezdirme mesajı ile insanı doğruya, güzele yönlendirir (Karakaya, 1998).

Kaşgarlı Mahmut'un Dîvânü Lugati't-Türk adlı ansiklopedik kitabında dil hassasiyeti, Ömer Seyfettin'in Forsa'sı ve Halide Edip Adıvar'ın Ateşten Gömlek'inde vatanseverlik ve dayanışma, Reşat Nuri Güntekin'in Yaprak Dökümü'nde aile sevgisinin önemi (Eskimen, 2018a), Mevlana'nın Mesnevi'sinde ahlak, Yunus Emre'nin şiirlerinde sabır, çocuk masallarında iyilik (Karakaya, 1998) edebiyat ürünlerinin alenen veya gizil olarak yansıttığ değerlere örneklerdir.

Anthony Burgeskült eseri Otomatik Portakal'da (2017) on altı yaşındaki kahramanı Alex'i "modern dünyanın zavallı kurbanı" olarak tarif eder. Yazarın toplumsal bütün değerlerden yoksun karakterini bir zavallı olarak görmesinin nedeni toplumun ceza aygıtının devreye girerek Alex'i makinalar ile "1slah" etmesi yani bir nevi kendi değer yargıları içerisine dâhil etmesidir. Bu zorla dâhil etme anında Alex'in herhangi bir kabul veya ret seçeneği yoktur. Yazara göre seçil(e)meyen değer yargıları bireyi iyi veya kötü gibi bir değer yargısına sahip yapmaz. Dolayısıyla değerler eğitiminde dikkat edilmesi gereken en önemli nokta öğrencilere değerleri ezberletmenin ötesine geçerek onların istenilen değerleri içselleştirmelerine yardımcı olmak olmalıdır. Bu bir anlamda toplumsal değer yargılarını benimsemesi beklenen bireyin toplum içindeki özerkliğine duyulması gereken saygıyı da ifade eder. Millı Eğitim Temel Kanunu'nda (MEB, 1973)millî eğitimin temel ilkeleri başlığı altında"ferdin ve toplumun ihtiyaçları" ifadesine yer verilmesi de birey ile toplum arasındaki dengeye işaret etmesi açısından bu minvalde okunabilir. 
Türkçede tasavvufî manâ dilinin kurucusu (Tatcı, 2016) olarak tanımlanan ve şiirlerinde edep, çalışkanlık, adalet, dürüstlük, sevgi, saygı, yardımseverlik gibi hem dini hem de kültürel değerleri sıkça işleyen Yunus Emre'nin değer öğretilerinin Türk dili ve edebiyatı derslerinde doğrudan veya dolaylı olarak konu edinilmesi bir gerekliliktir. Yunus Emre'nin değer öğretilerini şiir dili ile estetikleştirerek aktarması öğrencinin yorum ve düşünce kabiliyetini de harekete geçirerek öğrencilerin şiirdeki değerler hakkında kritik yapmalarını sağlar.

Kaplan'a göre (1973) Yunus Emre, şiirlerinde bireysel duygularını değil insanın var olan doğasını anlatır. İnsan doğasının sevgi ile nefreti, iyilik ile kötülüğü, adalet ile zulmü, dürüstlük ile ihaneti aynı anda barındırdığı düșünüldüğünde bu anlamlıdır. Zira Yunus Emre hemen her şiirinde insanın içindeki benliği yani özündeki değerleri kaybetmemesi gerektiğini vurgular. Bu nedenle ona göre insan hayatında varılması gereken yer, aynı zamanda geçilen yerdir: doğuştaki saflık.

Başka bir şiirinde insan tabiatını anâsır-1 erba -ateş, su, rüzgâr, toprak- ile sembolize eden Yunus Emre; sabrı, saygıyı, tevekkülü, iyiliği yüceltirken yalanı, ikiyüzlülüğü, kibri ve kıskançlığı kaçınılması gereken kötü duygular olarak tanımlar:

Toprağıla bile geldi dört sıfat

Sabr u iyi hu tevekkül mekrümet

$$
\begin{aligned}
& \text { Suyıla geldi bile dört dürlü hal } \\
& \text { Ol safadur hem sehalutf } u \text { visal }
\end{aligned}
$$

Yil ile geldi bile bil dört heves

Oldur kizb ü riya tizlik nefes

\section{Odıla geldi bile dört dürlüdad}

Şehvet ü kibr ü tama birle hased (Kaplan, 1973, s. 66)

Yunus Emre "su ve toprağa mensup olan sakin, sabırlı ve barışçı insanları yüceltir" (Kaplan, 1973, s. 69). Zira su temiz ve berraklığı; toprak, yaratılışı ve özü temsil eder. Bu nedenle "miskîn Yunus erenlere tekebbür olma toprak ol" (Tatc1, 2016, s. 112) cümlesi insanın her daim özdenetimini yapmaya ve kendini unutmamaya olan bir çağrıdır.

Yunus Emre, başka bir şiirinde de insana dair bütün eğitsel çabanın nihai amacının aslında insanın kendine ve özündeki değerlerine ulaşmak olduğunu vurgular:

\section{Ilim ilim bilmekdir ilim kendin bilmektir}

Sen kendini bilmezsen bu nice okumaktır (Tatc1, 2016, s. 144)

Değer öğretisinin merkezinde insan, insanın merkezinde ise gönül vardır. İnsan gönlü kırılmaması, kirletilmemesi ve daima cümle kötü duygulardan uzak tutulması gereken yerdir. Öyle ki ona göre gönül yapmak hacca gitmek ile eşdeğerdir:

Bir kez gönül yıkdın ise bu kıldığın namaz değil,

Yetmiş iki millet dahi elin yüzün yumaz değil (Tatc1, 2016, s. 180)

Yunus Emre der hoca gerekse var bin hacca

Hepisinden iyice bir gönüle girmektir (Tatc1, 2016, s. 144) 
Yunus Emre'nin değer öğretisinin temelinde onun dünya algısı, dünya algısının temelinde ise dervişliği vardır. Derviş; tıpkı toprak ve su ile hayat bulan, etrafına fayda sağlayan bir ağaç gibidir (Kaplan, 1973). İnsanların zahirden geçip sîrete dalıp mana dünyasını görmelerine çabalamış (Özdemir, 2021) ve tıpkı bir ağaç gibi bütün insanlığı kendi gölgesine çekmeye çalışmış; sabrı, kanaati, adaleti, dostluğu, sevgiyi telkin etmiştir. Bu anlamda Yunus Emre, hem ulusal hem evrensel değer öğretilerini şiirle buluşturan ve okuruna insanlığın kaybetmemesi gerektiği değerleri hatırlatan bir hatırlatıcıdır.

\section{Türk Dili ve Edebiyatı Dersinde Film Kullanımı ve "Yunus Emre: Aşkın Sesi”" Filmi}

Kutsal kitaplardan antik dönem eserlerine kadar ilk yazılı kaynaklarda öğreticiliği önceleyen hikâyelere yer verilmiştir. Sözü edilen eserlerde insanla ilgili olanı taklit (mimesis) yolu ile yansıtarak fayda sağlamak amaçlanmıştır (Karakaya, 1998). Nihayetinde edebiyat, var olanı hikâyeleştirmekten, kurgulamaktan doğmuş ve zaman içerisinde kurgusal taklit yerini genel anlamda yaratıcı kurguya bırakmıştır. İster taklit ister kurgu olsun bütün edebî söylemin çıkış noktasını hissi, düşünceyi anlatmak ihtiyacı oluşturmuştur. Çünkü hikâye etmek ve hikâye edileni dinlemek insan için her zamanda bir gereksinim olagelmiştir. Edebiyat ve sinemanın ortak paydası da budur: anlatmak ve dinlemek gereksinimi (Eskimen, 2019). Tıpk1 edebî metinlerde olduğu gibi sinema eserlerinde de kurgusal bir dünya yaratımı söz konusudur (Eskimen, 2018b). Bu nedenle sinema dilinin ve kurgu dünyasının gelişiminde özellikle kurguya dayalı bir metin olarak romanların büyük etkisi olmuştur. Romanlar bazen kurgu, bazen uyarlama, bazen de ticarî yönüyle sinema dilini ve yaratımını etkileyen en önemli tür olarak karşımıza çıkar (Çakır, 2019). Sinema edebiyatın estetik dilini ve kurgusunu senaryosunda kullanarak sözcüklerin büyülü dünyası ile görselliğin imgeler dünyasından muazzam bir yenidünya yaratır (Yüce, 2005). Bu ilişki sinemayı "görsel roman" olarak tanımlamayı mümkün kılar. Romanın görselliğini okurun zihni yaratımına bırakan soyutluğunun yerine sinema sözcüklere görsellik, ses katarak doğrudan kendi sunar (Can \& Uğurlu, 2010). Dolayısıyla denilebilir ki modern çağın olağanlığında olağanüstü bir şekilde yedinci sanat olarak doğan sinema, nispeten kısa süren çocukluğunu ve hızlı yetişkinliğini edebiyatın çağlar süren birikimine borçludur.

Edebiyat eserlerinin dil gücüne karşılık sinemanın görsel gücü yadsınamaz. Alain Robbe-Grillet de "sinema artık genç nesiller için edebiyattan çok daha güçlü bir tutkuya" (akt. Gögercin, 2003, s. 115) dönüştüğünü vurgular. Zaman içinde sinema ile edebiyat ilişkisi hem birbirini besleyen hem de birbiri ile yarışan bir hal almıştır. Edebiyatın sinemaya hedef kitle, malzeme, okur kitlesi sunması sinemayı besleyen temel yapı taşlarını oluşturur (Can \& Uğurlu, 2010). Buna karşın sinemanın da edebiyata üstün gelen yönleri vardır.

Sinemanın edebiyatta olmayan ses, görüntü gücü bu yönün en önemli unsurunu oluşturur. Sinemanın düşsel olanı görsel olana aktarma gücünü Wittgenstein'ın "gösterilebilir olan söylenemez" (Wittgensteın, 2018, s. 63) sözü ile ifade doğru olacaktır. Zira bazen söylenebilir olanı göstermek bazen de gösterilebilir olanı yazıya dökmek mümkün olmayabilmektedir.

Sinemanın eğitici yönünün keşfi Lumiére Kardeşler'in 1895'te film makinesini buluşu yıllarına dayanır. Bu keşifte sinemanın edebiyat, müzik, mimari, dans, tiyatro gibi farklı sanat dallarını aynı dilde buluşturması etkili olmuştur (Yakar, 2013). Sinemanın Türk dili ve edebiyatı derslerinde kullanımının hem doğallığı hem de gerekliliği sinema ile edebiyatın yukarıda açıklanan ilişkisine dayanır. Ders kitaplarının sadece yazılı bilgi ve resim aktarabilmesine ve bilgiyi öğrencinin gayretine bağlayan yapısına karşın filmler hem görsel işitsel bilgi sunar hem de sunduğu bilgiyi öğrenci zihnine süreğen şekilde iletir (Birkök, 2008). Başta görsel-işitsellik ve öğrencinin dikkatini çekme olmak üzere filmlerin Türk dili ve edebiyatı derslerinde kullanımının çokça faydası vardır. Filmler ayrıca Ortaöğretim Türk Dili ve Edebiyatı Dersi (9,10, 11 ve 12. Sinıflar) Öğretim Programı'nda (MEB, 2018, s. 12) da yer verilen eleştirel 
düşünme, yaratıcı düşünme, medya okuryazarlı̆̆ı, görsel okuryazarlık, iletişim ve işbirliği gibi alana özgü becerilerin gelişimine de katkı sağlar.

Derse yönelik film seçiminde hedef kazanımlara, hedef kitlenin beklentisine, sınıfın fiziksel şartlarına, karşılanabilir maliyetine, süresine dikkat edilmelidir (Eskimen, 2018b). Aksi durumda film etkinliğinin öğretim amacına hizmet etmesi mümkün olmayacaktır. Sözü edilen etkenler dikkate alınarak seçilen filmin derste uygulanması aşamasında ise şu hususlar göz önünde bulundurulmalıdır:

- Film gösterim sıras1, sonras1 yapılacak etkinlikler planlanmalı,

- Ders öncesi gösterim araçlarının çalışır durumda olup olmadığı kontrol edilmeli,

- Film ile ilgili etkinliğe başlamadan önce etkinliğin amacı ile ilgili, ekinlik sırasında ve sonrasında yapılacaklarla ilgili gerekli açıklamalar yapılmalı,

- Filmlerin kurgusal bir ürün olduğu dolayısıyla karşılaşılan her bilginin doğru olmadığı bu anlamda filme eleştirel yaklaşılması gerektiği belirtilmeli,

- Film ile ilgili araç gereçler (mektup, fotoğraf, gazete haberi, afiş vb.) hazır bulundurulmal1,

- Film izlemeden önce önceden çoğaltılmış film çalışma kâğıdı öğrencilere dağıtılmalı,

- Burada yer alan sorulara göre öğrencilerin film izleme sürecinde dikkat etmesi gereken hususlar belirtilmeli, bunlara dair notlar tutabilecekleri hatırlatılmalı,

- Film sirası ve sonrası ekinliklerin süresi tespit edilmelidir (Demircioğlu, 2007; Öztaş, 2010; Öztaş, 2014).

Eğitimde hedeflenen değerler eğitiminin bilinçsiz bir tekrar ve telkin döngüsünden kurtulması için kazanımlara uygun film etkinliklerine yer verilmesi uygun olacaktır. Türk dili ve edebiyatı dersi de hem ders kazanımları açısından hem de edebiyat ile filmin yakın ilişkisinden bu etkinliklerin uygulanmasına en elverişli derslerden biridir. Filmlerin izleyicinin bilinçaltını farkında olmaksızın dahi etkilemesi (Karakaya, 1998), öğrencilere bireysel veya grup olarak konuyu tartışma imkânı sağlaması filmleri değerler eğitiminde de kullanılabilir materyale dönüştürmektedir. Zira yaşanılan çağda artık "şunu yap, bunu yapma yollu bir değer eğitimi gerçekleștirilememektedir" (Cemiloğlu, 2020). Bu nedenle yukarıda yer verilen etkenler de göz önüne alınarak çalışma amacı bağlamında Yunus Emre: Aşkın Sesi filmi seçilmiştir.

Alan yazınında Yunus Emre'nin değer öğretisini konu alan çalışmaların (Altıntaş, 2012; Açıkel, 2018; Cemiloğlu, 2020; Dilmaç \& Şimşir; Cemiloğlu, 2020; Çakır, 2019) genellikle kuramsal nitelikli çalışmalar olduğu ifade edilmelidir. Söz konusu çalışmanın önemini değerler eğitimi ile ilgili teorik bilgilerden hareketle değerler eğitimine yönelik Türk Dili ve Edebiyatı dersinde kullanılabilir materyal olarak Yunus Emre: Aşkın Sesi sinema filmini değerlendirmek ve önerilerde bulunmak oluşturmaktadır. Bu önem doğrultusunda biyografik ve Yunus Emre'nin değer öğretisini yansıtan bir film olarak Yunus Emre: Aşkın Sesi değerler eğitimi açısından değerlendirilmiştir.

\section{Yöntem}

Araştırmada nitel araştırma yöntemlerinden "doküman incelemesi" kullanılmıştır. Doküman incelemesi "Araştırılması hedeflenen olgu veya olgular hakkında bilgi içeren yazılı materyallerin analizini kapsar" (Yıldırım \& Şimşek, 2008, s. 187). Bu kapsamda çalışma materyalini amaçlı (amaçsal) örnekleme ile seçilen ve yönetmenliğini Kürşat Kızbaz'ın yaptığı Yunus Emre: Aşkın Sesi filmi oluşturmuştur. Amaçlı örnekleme seçkisiz olmayan örnekleme yöntemlerinden olup "olasılı olmayan, seçkisiz olmayan bir örnekleme yaklaşımıdır. Amaçsal örnekleme (purposive/purposeful sampling), çalışmanın amacına bağlı olarak bilgi açısından 
zengin durumların (intormation-rich cases) seçilerek derinlemesine araștırma yapılmasına olanak tanır" (Büyüköztürk ve diğerleri, 2019, s. 92). Ayrıca amaçlı örneklemle seçilen örneklemin araştırma hedefine uygun zengin bilgi sunması hedeflenir(Büyüköztürk ve diğerleri 2019, s. 258; Patton, 2018, s. 46)".

Doküman incelemesi ile elde edilen bulgular nitel veri analizi yöntemlerinden içerik analizi ile analiz edilmiştir. İçerik analizi "metin veya metinlerden oluşan bir kümenin içindeki belli kelimelerin veya kavramların varlığını belirlemeye yönelik yapılır" ve "Araştırmacılar...metinlerdeki mesaja ilişkin çıkarımlarda bulunurlar" (Büyüköztürk ve diğerleri, 2019, s. 259). İçerik analizi ileelde edilen“kök değerler"e (MEB, 2018) ait bulgulara ilişkin bir tablo verilmiş ve her bulgu alt başlıklarda Yunus Emre şiiirleri ile değerlendirilmiştir.

\section{Bulgular ve Yorum}

Çalışmada ele alınan Yunus Emre: Aşkın Sesi, senarist ve yönetmenliğini Kürşat Kızbaz'ın üstlendiği, 2014'te çekilen doksan yedi dakika süreli bir sinema filmidir. Filmi Türk dili ve edebiyatı dersi için önemli kılan Türkçeye anlam katan Yunus Emre'nin hayatını konu ediniyor olmasıdır. Filmde Yunus Emre'nin hayatından kesitler şu şekilde aktarılır: Film, Yunus Emre'nin Moğol saldırılarını simgeleyen bir rüyadan uyanması ile başlar. Köyünde kuraklık nedeniyle kıtlık yaşanınca köyden bir kadın Yunus'a gelerek hem buğday ister hem de Yunus'un Hacı Bektaş-1 Veli'ye giderek buğday talep etmesini ister. Yunus Emre, elinde biraz alıçla Hacı Bektaş-1 Veli’ye giderek buğday talep eder. Hacı Bektaş-1 Veli her ne kadar buğday yerine nefes vermeyi talep etse de Yunus Emre buğdayda 1srar eder ve buğday1 alarak yola çıkar. Yolda hatasını anlayan Yunus Emre, dergâha geri döner ve nefese talip olur. Yunus Emre'nin nefesle nefis yolculuğu böyle başlar. Tapduk Emre'nin tedrisatından da geçen Yunus Emre, bitmeyen benlik arayışında hiçlik makamına erişir.

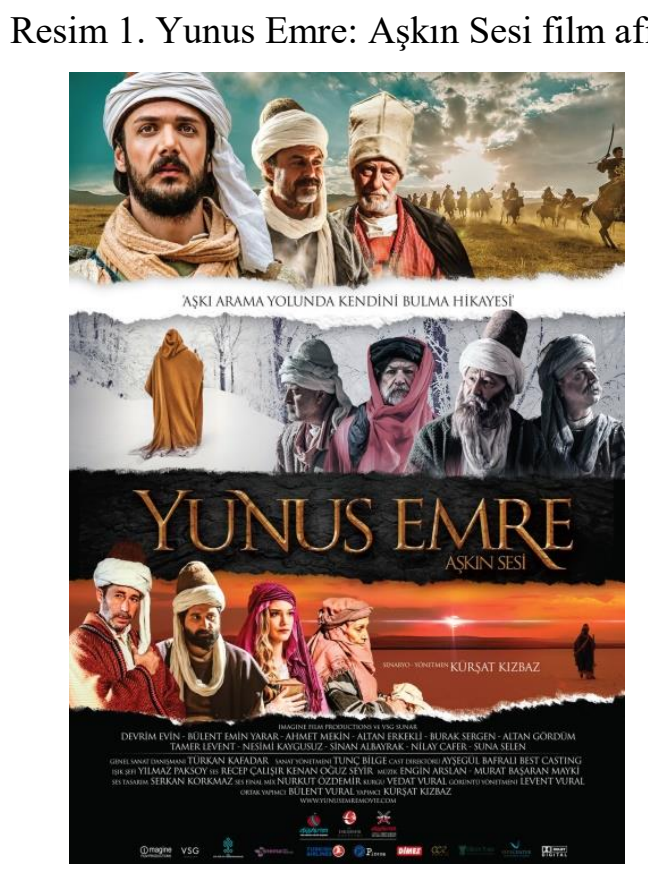


Tablo 1. Yunus Emre: Așkın Sesi filmindeki kök değerlere ilișkin bulgular

\begin{tabular}{ll}
\hline Kök Değerler & $F$ \\
\hline Adalet & 0 \\
\hline Dostluk & 1 \\
\hline Dürüstlük & 1 \\
\hline Özdenetim & 4 \\
\hline Sabır & 2 \\
\hline Sayg1 & 2 \\
\hline Sevgi & 21 \\
\hline Sorumluluk & 3 \\
\hline Vatanseverlik & 1 \\
\hline Yardımseverlik & 2
\end{tabular}

Frekans tablosuna göre Yunus Emre: Aşkın Sesi sinema filminde en çok yer verilen değer sevgi hiç yer verilmeyen değer adalet olmuştur.

\section{- Adalet}

Filmde adalet değerine ilişkin bulguya yer verilmemiştir.

\section{- Dostluk}

Yunus Emre'nin dostluk anlayışı yaratanın sevgisine muhatap olmaktan doğar. Ona göre yaratana ulaşmak, yaratılmış olan her şeye saygılı davranmayı gerektirir. Dünyada var olanla dostluk asıl dost olan yaratana ulaşmak için bir vesiledir:

Bu dünyaya kalmayalım,

Fânidir aldanmayalım

Bir iken ayrlmayalım

Gel dosta gidelim gönül (Tatc1, 2016)

Filmde dostluk Hacı Bektaş-1 Velî’nin Yunus’a söylediği şu sözle vurgular: "Kapımız dost gönüllülere açıktır".

\section{- Dürüstlük}

Yunus Emre'nin bütün duygu ve düşüncelerini yöneten ana etken insanın kendisinin farkında olma durumudur. Ona göre kendini bilen başka bir ifade ile insan olmanın kıymetinin farkında olan insanın yalan söylemesi mümkün değildir:

\section{İyYunus Hakk’ı bilen söylemez hergiz yalan}

İkilik ile gelen togrl yol bulmışdegül (Özdemir, 2021, s. 574)

Filmde dürüstlüğe, yalan söylememek üzerinden vurgu yapılmıştır: Hacı Bektaş-1 Velî şöyle der: "Doğruluktan ve iyilikten kaçınmayız oğul".

\section{- Özdenetim}

Yunus Emre'ye göre öz denetim, olumlu olumsuz bütün duyguları kendinde barındıran insanın kötülügü simgeleyen nefsi ile mücadelesinden geçer. İnsanı kötülüğe sevk eden nefis mücadele edilmesi gereken bir düşmandır:

\section{Sakıngılkimbulardan olmayasin}

Ki nefs divanina yazllmayasın (Tatc1, 2016)

İnsan, içindeki kötülüklerden arınmak için içindeki kötülüklere dışarı çıkarmadan engel olmalidır: 
İçeri gizlidir cümle yavuz hu

Gider gösterme kimseye anı yu (Tatc1, 2016)

Filmde insanın kendi kontrolüne yönelik şu ifadelere yer verilmiştir:

"Ĕ̆er konuşursan hikmetle konuş, oturacağın zaman hürmetle otur"

"Dervişlik zor iştir Yunus Efendi. Zordur odun toplamak dağlardan. Zordur derviş olmak, teslim olmak. Çok gelen oldu senin gibi. En güçlüsü on gün dayanamadı."

"Şimdi söyle bakalım Yunus can. Kimsin sen? İçindeki ışılkla bakmadan gör"

"Önce nefsini, kendini yok etmelisin"

\section{- Sabir}

Gelenekte Yusuf ve Eyyüp peygamberle özdeşleşen sabır, Yunus Emre'de zorluklara göğüs germek ve nihâyetinde istenilen duruma ulaşmayı ifade eder.

Ne sarp iş olsa sabr anı bitirür,

Kamyiren saadetler getürür (Kaplan, 1973, s. 75)

Filmde sabır telkini Yunus Emre'nin Tapduk Emre'nin dergâhına usanmadan, şikâyet etmeden odun taşıması ile yapılmıştır.

\section{- Saygı}

Yunus Emre'ye göre saygı, insanın kendinin farkında olup kibirlenmeden yaratılana yaratandan ötürü hürmet göstermesidir. Ona göre yaratımın doğasında olan farklılıkları öne sürerek saygısızlık yapmak âsiliktir:

Yetmiş iki millete birlik ile bakmayan

Şer'i ile evliya ise hakikatte âsidir (Tatc1, 2016, s. 121)

Saygıyı öldüren kibir ise savaşılması gerekendir:

Sakıngılolmagılkibr ile yoldaş

Kibir kandayısa onunla savaşs (Tatc1, 2016, s. 73)

Özünden gayrl kimseyi beğenmez,

Yüce yirdeturur aşă̆ı inmez (Kaplan, 1973, s. 72)

Tekebbür kişiler ere inemez,

Özinündüşmanıdurur göremez (Kaplan, 1973, s. 72)

Filmde mürşidi Tapduk Emre kendisine söz söylemesini isteyince Yunus Emre, sayg1 ve tevazu ile şöyle der: "Bir damlacık su okyanusa nasıl hediye edilir. Bir altın zerresi alınıp altın madenine nasıl hediye edilir?". Ayrıca Yunus Emre; evine gelen, hiç tanımadığı kadına saygı ile hürmet gösterir.

\section{- Sevgi}

Yunus Emre'de sevgi; çıkarsız, saf ve karşılık beklemeden olan duygulanımdır. Eğer beklenen cennet dahi olsa bu aşk değildir:

Âşık mı diyem ben ona Tanrı'nın Uçmağı'n seve,

Uçmak dahi tuzak imiş mü'mincânların tutmă̆a (Tatc1, 2016, s. 15) 
Âșk; teslim olmak, kendi varlığını onda eritmektir. Kendini aşktan, sevmekten mahrum bırakan birinin taş gibi bir nesneden farklı yoktur:

Âşık kişi miskin olur yol içinde teslim olur

Kim n'iderse boyun bura çare yok gönül yıkmă̆a (Tatc1, 2016)

İşidin ey yârenler aşk bir güneşe benzer

Aşkı olmayan gönül misal-i taşa benzer (Tatc1, 2016, s. 131)

Filmde aşka, sevgiye yönelik cümlelere örnekler:

"işitin ey yarenler aşk bir güneşe benzer, klymetli nesnedir aşk. Gönüllere yol eyler, sultanlarl kul eyler.Hikmetli nesnedir aşk, Denizleri kaynatur, kayaları söyletir. Kuvvetli nesnedir aşk."

"İşitin ey yarenler, aşk bir güneşe benzer, aşkı olmayan gönül misali taşa benzer"

"Dervişlik dedikleri hırka ile taç değil

Gönlünü derviş eyleyen hırkaya muhtaç değil,

Aşksızlara verme öğ̈̈t,

Öğ̈̈dünden alır değil”"

"Gurbet elinde yürürüm,

Dostu düşümde görürüm,

Uyanıp Mecnun olurum,

Gel gör beni aşk neyledi"

“Ĕger göğ̈̈n yedi kat üstüne çıkmaksa niyetin,

Aşk'tan güzel merdiven bulamazsın..!

Ĕger Aşk'ı bulmaksa niyetin,

Aramadan duramazsin..!"

"seven ve kalbini temiz tutan dağları ve okyanusları bile aşar"

\section{- Sorumluluk}

Filmde sorumluluğu vurgulayan örnek cümleler:

"Cemal Seyit var git şimdi Toroslara. Kur dergâhını orada. Gönülleri mest eyle. Güzel sözler söyle."

"Ne verirsen topră̆a onu alırsın, ne ekersen onu biçersin."

"Bilirim ki sizin kapınızdan hiçbir eğrilik girmez. Odunun bile ĕgrisi bu dergâha yakışmaz.” 


\section{- Vatanseverlik}

Yunus Emre'ye göre devlet bir nefestir. Erenlerin inancında ise devlete karşı fitneye, kavgaya yer yoktur:

\section{Erenler nefesidir devletimiz}

Anınçün fitneden olduk selâmet (Tatc1, 2016, s. 180)

Bize didâr gerek dünya gerekmez

Bize mâna gerek davâ gerekmez (Tatc1, 2016, s. 148)

\section{Bir kimsenin devletine ta'nidüben giz gelmeziz}

Ne münkiriz âlimlere ne tersanınhâçındanız (Tatc1, 2016, s. 154)

Filmde vatan için mücadele sözlü olarak vurgulanmayıp Moğollara karşı verilen mücadele sahnesinde örtük şekilde vurgulanmıştır.

\section{- Yardımseverlik}

Yunus Emre; şiirlerinde cimriliği eleştirirken zekât vermeyi, cömertliği, eli açıklı̆̆ı, yardım etmeyi öğütler:

\section{Kazancın kendinin kendüye vermez}

Eli bağlı durur ye0meğe ermez (Tatc1, 2016, s. 76)

\section{Zekatın vermeyenin hali budur}

Olur boynuna zencir malı budur (Tatc1, 2016, s. 77)

\section{Akıl eydür gel e bir gözlerin aç}

Sehavet kanda ise ol yana kaç (Tatc1, 2016, s. 77)

Filmde Yunus Emre'nin tanımadığı bir kadın gelerek çocukları için bir tutam buğday ister. Yunus Emre ise "Ana al, benim buğdayım senindir. Hepsini çocuklarına götür" diyerek elindeki tüm buğdayı verir. Ayrıca filmde Hacı Bektaş-1 Velî̀den "O açların karnını doyurur. Muhtaçlara yardım eder" diye bahsedilir.

\section{Tartışma, Sonuç ve Öneriler}

Çalışmada Yunus Emre, onun Türk insanının kültürel belleğindeki yeri, sevgi, sayg1, hoşgörü, Türkçe sevgisi ve dahi pek çok öğretisinin toplumun geleceği olan gençlere film yoluyla aktarılması üzerinde durulmuştur. Yunus Emre: Aşkın Sesi filmi kök değerler açısından değerlendirilmiş ve en çok yer verilen değerin aşk, en az yer verilen değerin sevgi olduğu tespit edilmiştir. Genel olarak eğitim-öğretimde, özel alanda ise dil ve edebiyat öğretiminde öğrencilerin dikkatini çekerek, motivasyonunu sağlayarak, zaman zaman görsel işitsel yollarla bilginin aktarılması ve bu yolla kalıcı mahiyette kazanımların elde edilmesi esastır. Dolayısıyla, Türk Dili ve edebiyatı dersi gibi edebî metinler çerçevesinde ele alınan bir dersin film gibi insanların anlatma ve anlama gereksinimleri dolayısıyla ortaya çıkmış başka bir disiplinle ilişkilendirilerek ele alınması önemlidir. Yunus Emre'nin şiirlerinde değerlerin ele alınmasına yönelik Açıkel (2018) tarafından yapılan çalışmada Yunus Emre'nin şiirleri değerler eğitimi açısından ele alınmıştır. Bu araştırmanın bulguları hem Yunus Emre: Aşkın Sesi filminin hem de 
Yunus Emre'nin şiirlerinin değerler eğitimine uygunluğunu gösterdiği için söz konusu çalışma sonuçları ile uyumludur.

Çalışmadan elde edilen veriler içerisinde Yunus Emre'nin Yunus Emre: Aşkın Sesi filminde sevgi değerine sıklıkla vurgu yapılmıştır. Aşkı, sevgiyi yaratışının nihai amacının aracı olarak gören Yunus Emre aşkı kalbinde aramış, bulduğu duyguyu bütün insanlara söz ile miras bırakmıştır. Yunus'un dilsel mirasını görsel şekle dönüştüren Yunus Emre: Aşkın Sesi filmi hem Yunus Emre'nin hayatını konu alması hem de Yunus'un şiirlerle dile getirdiği değer öğretimini görsel-işitsel şekilde sunması açısından önemlidir. Araştırma sonuçları çerçevesinde sunulabilecek öneriler şunlardır:

- Dersin kazanımlarına göre ihtiyaç duyulan değeri içeren filmlere belli program dâhilinde derste yer verilebilir.

- Türk dili ve edebiyatı dersi hem kazanımları hem de amaçları bakımından değerler eğitiminin gerçekleşmesine en uygun derstir. Bu nedenle Türk dili ve edebiyatı dersinde değerler eğitimine yönelik film etkinlikleri hazırlanabilir.

- Söz konusu çalışmada Yunus Emre: Aşkın Sesi filmi sadece kök değerler açısından değerlendirilmiştir. Türk Dili ve edebiyatı dersine konu olan- özellikle uyarlamafilmler kök değerler dışında kalan değerlerin öğretiminde de değerlendirilebilir.

- Uyarlama filmler ile uyarlama yapılan kitaplarla eşgüdümlü şekilde etkinlik programı yap1labilir.

- Hedef kitle ile kazanımlar çerçevesinde değerler eğitimine yönelik Türk dili ve edebiyatı ders kitaplarında izlenecek filmler etkinliğine yer verilebilir.

\section{Kaynakça}

Açıkel, F. (2018). Yunus Emre'nin eserlerinde değerler eğitimi unsurlarının tespiti.(Yayımlanmamış Yüksek Lisans Tezi) Kırıkkale Üniversitesi, Kırıkkale.

Altıntaş, M. E. (2012). Bireycilik ve toplumculuk tartışmaları bağlamında değerler eğitimi yaklaşımı. Değerler Ĕ̈itimi Dergisi, 10(24), 31-54.

Alver, K. (2006). Edebiyat ve kimlik. Bilgi Sosyal Bilimler Dergisi(2), 32-43.

Birkök, M. C. (2008). Bir toplumsallaştırma aracı olarak eğitimde alternatif medya kullanımı: Sinema filmleri. Uluslararası Insan Bilimleri Dergisi, 5(2), 1-12.

Burges, A. (2017). Otomatik portakal. (D. Körpe, Çev.) İstanbul: İş Bankası Yayınları.

Büyüköztürk, Ş., Çakmak, E. K., Akgün, Ö. E., Karadeniz, Ş., \& Demirel, F. (2019). eğitimde bilimsel araştırma yöntemleri(26. b.). Ankara: Pegem Akademi.

Can, A., \& Uğurlu, F. (2010). "Gölgesizler" filmi ve edebiyat sinema ilişkisi üzerine.Selçuk Iletişim, 6(3), 76-84.

Cemiloğlu, M. (2020). Türk dili ve edebiyatı dersinde değerler öğretimi. Uluslararası İnsan ve Sanat Araştırmaları Dergisi, 3(4), 17-23.

Chomsky, N. (2013). Demokrasi ve eğitim. İstanbul: bgst.

Çakır, S. (2019). Sinema ve edebiyat ilişkisine yöntemsel bir bakış. SineFilozofi Dergisi(Özel Say1), 2547-9458.

Demircioğlu, İ. H. (2007), “Tarih öğretiminde filmlerin yeri ve önemi”. Bilig, 42, 77-93.

Dilmaç, B., \& Şimşir, Z. (2016). Okullarda değerler eğitimi.

Eskimen, A. D. (2018a). 2018 yılı Türk dili ve edebiyatı öğretim programı ve 9.-10. sınıf türk dili ve edebiyatı ders kitaplarında yer alan değerler. The Journal of Academic Social Science Studies(66), 51-67. 
Eskimen, A. D. (2018b). Using films in teaching of language and literature secondary education level.New Horizons in Educational Sciences- II (p. 195-206). içinde Riga: LAP- Lambert Academic Publishing.

Eskimen, A. D. (2018c), "Edebiyat öğretimi ve sinema- bir film izleme etkinliği”, Bilkent Üniversitesi XIII. Uluslararası Büyük Türk Dili Kurultayı Bildirileri Kitabı, 25-28 Eylül 2018,Polonya-Varşova, Meteksan Matbaacılık ve Teknik Sanayi Ticaret A.Ş.

Gögercin, A. (2003). Edebiyat ve sinema ilişkisinde farklı bir örnek:Roger Grenie'in "Sine roman"1. Selçuk Illetişim, 3(1), 115-124.

Kaplan, M. (1973). Yunus Emre'nin İnsan ve ahlâk görüşü (Risalat al Nushiyya'nın tahlili). İstanbul Üniversitesi Edebiyat Fakültesi Türk Dili ve Edebiyatı Dergisi, 65 - 82.

Karakaya, Z. (1998). Öğretici ve eğitici edebiyat üzerine bir deneme. Ondokuz Mayls Üniversitesi Ë̆itim Fakültesi Dergisi, 11(1), 80 - 91.

Köprülü, M. F. (1976). Türk edebiyatında ilk mutasavvıflar(3 b.). Ankara: Türk Tarih Kurumu Basımevi.

MEB. (1973). Millî eğitim temel kanunu. $07 \quad 12,2021$ tarihinde https://www.mevzuat.gov.tr/MevzuatMetin/1.5.1739.pdf adresinden alındı

MEB. (2018). 07 10, 2021 tarihinde Ortaöğretim Türk dili ve edebiyatı dersi (9,10, 11 ve 12. sinıflar) öğretim programı: https://mufredat.meb.gov.tr/ProgramDetay.aspx?PID=353 adresinden alındı

Murat, M., Doğan, Ş. \& Öner, R.E. (2019). “Afacanlar Sınıfi” animasyon filmi ve kök değerler. International Social Sciences Studies Journal, 5(46): 5542-5563.

Nişanyan, S. (2020). $07 \quad 11,2021$ tarihinde Nişanyan Sözlük: https://www.nisanyansozluk.com/?k=de $\% \mathrm{C} 4 \% 9$ Fer adresinden alınd 1

Okay, O. (1994). Edebiyat maddesi. Türkiye İslam Ansiklopedisi (Cilt 10.) içinde İstanbul: Türkiye Diyanet Vakfi.

Öztaş, S. (2010). Tarih nasıl öğretilir? Tarih öğretmenleri için özel öğretim yöntemleri. Mustafa Safran (Ed.)Tarih derslerinde filmlerin kullanımı içinde (ss. 297-307). Ankara: Yeni İnsan Yayınevi.

Öztaş, S. (2014). Tarih öğretiminde öğretim teknolojileri ve materyal tasarımı İsmail H. Demircioğlu \& İbrahim Tufan (Ed.) Tarih öğretiminde filmlerin kullanımı içinde (ss. 163176). Ankara: Pegem Akademik Yayıncılık.

Özdemir, C. (2021). Bir şiir şerhi: Yunus'un dünyasında derviş kimliği. Uluslararası Türkçe Edebiyat Kültür Eğitim Dergisi, 10(2), 563-577.

Patton, M. Q. (2018). Nitel araştırma ve değerlendirme yöntemleri (2. Baskı b.). (M. Bütün, \& S. Demir, Çev.) Ankara: Pegem Akademi.

Reboul, O. (1995). Değerlerimiz evrensel midir? Eğitim Yönetimi(3), 363-374.

Şahin, H. (2011). Tapduk Emre. TDV İslam Ansiklopedisi (Cilt 40, s. 12-13). içinde İstanbul: Türkiye Diyanet Vakfi.

Tatc1, M. (2013). Yûnus Emre. TDV İslam ansiklopedisi (Cilt 43, s. 600-606). içinde İstanbul: Türkiye Diyanet Vakfi.

Tatc1, M. (2016). Yûnus Emre divan-seçmeler. Ankara: Diyanet İşleri Başkanlığı.

TDK. (tarih yok). 07 10, 2021 tarihinde https://sozluk.gov.tr/: https://sozluk.gov.tr/ adresinden alınd 1 
Urlu, E. (2020). Değerler eğitimi bağlamında Melih Cevdet Anday oyunlarının incelenmesi. Manisa Celal Bayar Üniversitesi Sosyal Bilimler Dergisi, 4(18), 49-66.

Wittgenstein, L. (2018). Tractatus logıco- phılosophıcus. (O. Aruoba, Çev.) İstanbul: Metis.

Yakar, H. G. (2013). Sinema filmlerinin eğitim amaçlı kullanımı: Tarihsel bir değerlendirme. Hasan Ali Yücel Eğitim Fakültesi Dergisi(19), 21-36.

Yaylacı, A. F. (2016). Değerler eğitimi ve bir fabrika olarak modern okul.Kırıkkale Üniversitesi Sosyal Bilimler Dergisi, 6(2), 153 - 172.

Yazıcı, K. (2006). Değerler eğitimine genel bir bakış. Türklük Bilimi Araştırmaları(19), 499522.

Yıldırım, A., \& Şimşek, H. (2008). Sosyal bilimlerde nitel araştırma yöntemleri (6. b.). Ankara: Seçkin Yayınevi.

Yüce, T. (2005). Sinema ve edebiyat türleri arasında görülen etkileşimler. ZKÜ Sosyal Bilimler Dergisi, 1(2), 67-74.

ETİK ve BİLİMSEL İLKELER SORUMLULUK BEYANI

$\mathrm{Bu}$ çalışmanın tüm hazırlanma süreçlerinde etik kurallara ve bilimsel atıf gösterme ilkelerine riayet edildiğini yazar(lar) beyan eder. Aksi bir durumun tespiti halinde Afyon Kocatepe Üniversitesi Sosyal Bilimler Dergisi'nin hiçbir sorumluluğu olmayıp, tüm sorumluluk makale yazarlarına aittir.

\section{ARAŞTIRMACILARIN MAKALEYE KATKI ORANI BEYANI}

1. yazar katk1 oran1 : \% 60

2. yazar katk1 oran1 : $\% 40$ 